Çerçi, A. ve Derman, S. (2016). Türkçe dersi etkinliklerine yönelik tutum ölçeği geliştirilmesi: Geçerlilik ve güvenirlik çalışması. Ana Dili Eğitimi Dergisi, 4(4), 461-473.

\begin{tabular}{c}
$\begin{array}{c}\text { Ana Dili Eğitimi Dergisi } \\
\text { Journal of Mother Tongue Education } \\
\text { www.anadiliegitimi.com }\end{array}$ \\
Gelis/Received: $24.05 .2016 \quad$ Kabul/Accepted: 22.09 .2016 \\
\hline
\end{tabular}

\title{
Türkçe Dersi Etkinliklerine Yönelik Tutum Ölçeği Geliştirilmesi: Geçerlilik ve Güvenirlik
}

\section{Çalışması}

\begin{abstract}
Arif ÇERÇi ${ }^{1}$
Serdar DERMAN²

Öz

Türkçe eğitiminde etkinlikler önemli yer tutmaktadır. Öğrencilerin etkinliklere karşı olan tutumlarının bilinmesi, Türkçe eğitiminin amaçlarına uygun etkinliklerin geliştirilmesi bakımından oldukça önemlidir. Bu çalışmada ortaokul öğrencilerinin Türkçe dersi etkinliklerini uygulamaya yönelik tutumlarını ölçebilecek nitelikte bir ölçek geliştirmek amaçlanmaktadır. Türkçe dersi etkinlikleri tutum ölçeğinin geliştirilmesinde, 7. sınıf öğrencilerinin etkinlikler konusundaki duygu ve düşüncelerinden hareket edilmiştir. Ölçek, 22 maddeden oluşmaktadır ve beşli likert tipindedir. Ölçeğin geçerlik ve güvenirliğine ilişkin çalışmalar, ortaokul 7.sınıf öğrencilerinden rastlantısal örnekleme yöntemiyle seçilen 526 öğrenciden derlenen verilerle gerçekleştirilmiştir. Ölçeğin yap geçerliliği faktör analiziyle belirlenmiştir. Ölçekteki maddelerin faktör yükleri .425 - .719 arasında değer almaktadır. KMO (Kaiser-Meyer-Olkin) değeri .962; iç tutarlık katsayı değeri ise .947'dir. Bu sonuçlar ölçeğin geçerlik ve güvenirlik değerlerine sahip olduğunu göstermektedir.
\end{abstract}

Anahtar Kelimeler: Türkçe etkinlikleri, öğrenciler, tutum ölçeği.

\section{Development of an Attitude Scale towards Turkish Course Activities:}

\section{A Validity and Reliability Study}

\begin{abstract}
Activities are of great significance in teaching Turkish. The knowledge of students' attitudes towards activities is rather important in developing activities that are in accord with the aims of teaching Turkish. The purpose of this study was to develop a scale to evaluate secondary school students' attitudes towards doing the activities in the Turkish course. The starting point for the development of the attitude scale for the activities in the Turkish course was the opinions and feelings of the $7^{\text {th }}$ grade students. The scale has 22 likert type items. The validity and reliability analyses of the scale were done with the data collected from $5267^{\text {th }}$ grade students who had been selected, using random sampling method. The construct validity of the scale was determined, using factor analysis. Factor loadings of the items in the scale ranged between .425 and .719. KaiserMeyer-Olkin (KMO) value was .962, and internal consistency was .947. These statistics showed that the scale had satisfactory validity and reliability values.
\end{abstract}

Key Words: Turkish course activities, students, attitude scale.

\footnotetext{
1 Yrd. Doç. Dr., Gaziantep Üniversitesi, Eğitim Fakültesi, Türkçe Eğitimi Bölümü. Gaziantep. E-posta: arifcerci@gmail.com

2 Yrd. Doç. Dr., Gaziantep Üniversitesi, Eğitim Fakültesi, Türkçe Eğitimi Bölümü. Gaziantep.

E-posta:serdarderman@gmail.com
} 


\section{Giriş}

Türkçe dersi öğretim programları, öğrencilere ana dillerini belirli bir düzeyde anlama, konuşma, okuma ve yazmalarını sağlamak için gerekli bilgi, beceri ve alışkanlıkları kazandırmanın yanında Türkçeyi doğru, etkili ve güzel kullanma, eleştirel ve yaratıcı düşünme, iletişim, problem çözme, araştırma, bilgi teknolojilerini kullanma, girişimcilikve kararverme gibi temel becerileri geliştirmeyi de amaçlamaktadır. Böylelikle eğitim sürecinin üst amacı olarak ifade edilebilecek Türk Millî Eğitiminin Genel Amaçlarına ulaşmak istenmektedir. (Kavcar, Oğuzkan ve Sever, 2005; MEB, 2006).

Türkçe dersi öğretim programında öğrenme alanları ve konular dikkate alındığında etkinlikleri altı başlık altında ele almak mümkündür:

1. Dinleme Etkinlikleri

2. Konuşma Etkinlikleri

3. Okuma Etkinlikleri

4. Yazma Etkinlikleri

5. Dil Bilgisi Etkinlikleri

6. Karma etkinlikler (birden fazla öğrenme alanını hedefleyen etkinlikler)

Bu etkinlikler yoluyla öğrencilerin bilgileri sıralama, sınıflama, ilişkilendirme, sorgulama, analiz ve sentez yapma gibi süreçlere tabi tutarak yeni bilgileri daha önceki bilgilerle bütünleştirmesi ve yeniden yapılandırması beklenmektedir (Kurudayıoğlu ve Çetin, 2015; Güneş, 2009).

Öğrencinin ön bilgilerle yeni bilgileri bütünleştirerek öğrenmeyi yeniden yapılandırmasında, bilişsel becerilerin ve dil becerilerinin geliştirilmesinde, etkinlikler önemli yer tutmaktadır. Çünkü son yıllarda Türkçenin örgün öğretimi kapsamında, etkinlik temelli bir yaklaşım benimsenmektedir. Bu durum etkinlik kavramına özel bir önem atfetmektedir. Nunan’a (2001) göre bir dil etkinlig̈inin tanımında belirleyici olan dört unsur söz konusudur: Bunlar hedefler, dilsel ya da dilsel olmayan bir girdi, bu girdiden kaynaklanan eylem, öğretmen ve öğrenci rolleridir. Richards and Rodgers'a (1986) göre etkinliklere ilişkin olarak benimsenen öğrenme yaklaşımı, strateji ve yöntemlere göre öğrenci rolünün gösterdiği özellikleri şu şekilde sıralamak mümkündür:

1. Öğrenci etkinlikte yer alan uyarıcıların pasif alıcısıdır.

2. Öğrenci uyarıııyı almanın yanında kendisi de uyarıcı veren bir uygulayıcı ve müzakerecidir.

3. Öğrenci etkinlik üzerinde çok az kontrole sahip olan bir dinleyicidir.

4. Öğrenci etkinliğin sağladığı kişisel gelişim sürecine katılmıştır.

5. Öğrenci sosyal bir etkinliğe katılır. Öğrencinin sosyal ve kişiler arası rolleri psikolojiköğrenme süreçlerinden kopuk değildir. 
Türkçe Dersi Etkinliklerine Yönelik Tutum Ölçeği Geliştirilmesi: Geçerlilik ve Güvenirlik Çalışması

6. Etkinlik öğrencilerin öğrenme özerkliği ve becerilerini geliştirmekte, öğrenci kendi öğrenmelerinin sorumluluğunu almaktadır.

Etkinliklerin hazırlanması, uygulanması ve değerlendirilmesi süreçlerinde öğrencinin etkinliklere yönelik tutumunun bilinmesi amaca uygun etkinliklerin geliştirilmesinde ve uygulanmasında oldukça önemlidir.

Alanyazında Türkçe dersine ve dil becerilerine yönelik tutumları ölçmeyi amaçlayan çeşitli çalışmalar (MEB, 2006; Çakıcı, 2005; Göçer, 2014; Gömleksiz, 2004; İşeri ve Ünal, 2010; Karasakaloğlu ve Saracaloğlu, 2009; Özbay, Bağcı, Uyar, 2008; Sallabaş, 2008; Özbay ve Uyar, 2009; Sevim, 2012; Ünal, 2006; Yalınkılıç, 2007; Yücel, 2005; Topçuoğlu Ünal ve Köse, 2014) bulunmakla birlikte Türkçe etkinliklerine yönelik ölçekleme temelli bir çalışmaya rastlanmamıştır.

2004 yılından itibaren MillîEğitim Bakanlığı yapılandırmacı öğretim yaklaşımınımerkeze alarak tüm öğretim programlarını yenilemiştir. Bu doğrultuda Türkçe Öğretim Programında da yapılandırmac yaklaşım merkeze alınarak öğretim programında çoklu zekâ, öğrenci merkezli öğrenme, beyin temelli öğrenme, bireysel farklılıklara duyarlıık, sarmal ve tematik yaklaşım, beceri ve etkinlik yaklaşımı gibi yaklaşım ve modellere yer verilmiştir. Türkçe öğretiminde dil becerilerinin geliştirilmesi sürecinde zihinsel, duygusal ve sosyal becerilerin geliştirilmesi de amaçlanmıştır (Güneş, 2013). Kısaca Programda Türkçe öğretiminin çeşitli etkinlik, görev ve projelerle yapılması, öğrencilerde dil ve zihinsel becerilerin etkinliklerle geliştirilmesi istenmektedir (Güneş, 2012). Yapılandırıı yaklaşımda etkinliklerin nasıl ve ne şekilde hazırlanacağı ile ilgili kısıtlayıı bir çerçeve bulunmamaktadır. Bu nedenle Türkçe öğre tim programında yer alan her türlü amaç, beceri ve kazanımlara yönelik olarak Türkçe ders kitaplarında çok çeşitli etkinliklere yer verilmektedir. Örnek olarak MEB (2015) 6. sınıf Türkçe dersi öğrenci çalışma kitabında 228 etkinlik yer almaktadır. Öğretme ve öğrenme sürecinde etkinliklerin bu denli kullanılması, öğrencilerin etkinliklere yönelik tutumlarının belirlenmesini zorunlu kılmaktadır. Çünkü “Kişinin belirli bir nesne ya da duruma yönelik tutumları bilinirse, bireyin o objeyeya da duruma yönelik tepkilerini tahmin etmede diğer değişkenlerle birlikte kullanılabilir. Eğitim sürecinin değerlendirilmesinde tutumlar uzun süreden beri dikkate alınan değişkenlerden biridir” (Özbay, 2009, s. 68). Sonuç olarak öğrencilerin Türkçe öğretiminde kullanılan etkinliklere yönelik tutumlarının belirlenmesi, öğretimin plânlanması, uygulanması ve değerlendirmesinde büyük bir önem taşımaktadır. Bu araştırma ortaokul öğrencilerinin Türkçe etkinliklerine yöneli k tutumlarını ölçebilecek bir ölçek geliştirmeyi amaçlamaktadır.

\section{Yöntem}

Bu çalışma, ortaokul öğrencilerinin Türkçe derslerindeki etkinliklere yönelik tutumlarını belirlemede kullanılabilecek geçerli ve güvenilir bir ölçek geliştirmeyi amaçlayan ölçekleme temelli bir 
araştırmadır. Çalışma, tarama modelinde gerçekleştirilmiştir. "Tarama modelleri, geçmişte ya da halen var olan bir durumu var olduğu şekliyle betimlemeyi amaçlayan araştırma yaklaşımıdır. Araştırmaya konu olan olay, birey ya da nesne, kendi koşulları içinde ve olduğu gibi tanımlanmaya çalışılır. Onlan herhangi bir şekilde değiştirme, etkileme çabası gösterilmez. Bilinmek istenen şey vardır ve oradadır. Önemli olan onu uygun bir biçimde gözleyip belirleyebilmektir” (Karasar, 2006, s. 77).

\section{Çalışma Grubu}

Araştırmanın çalışma grubu, 2015-2016 eğitim-öğretim yılının ikinci yarıyılında Gaziantep ilindeki devlet ortaokullarının 7. sınıflarında öğrenim görmekte olan 257 erkek (\%48.9) ve 269 kız (\%51.1) öğrenciden oluşmaktadır. Tavşancıl'a (2002) göre ölçekteki maddelerin en az beş katı kadar denek kullanılması madde ve faktör analizi için gereklidir. Öğrencilerin Türkçe dersi etkinliklerine yönelik tutumlarının 7. sınıflarda daha belirgin hâle geleceği düşüncesiyle çalışma grubuna 7. sınıf öğrencilerininalınması uygungörülmüştür. 7. sınıf düzeyinin hem etkinlik çeşitliliği (dil becerileri, metin türleri, dil bilgisi konuları vb.) bakımından zengin olması hem de bu düzeyde TEOG gibi merkezi sınavların olmaması çalışma grubuna 7. sınıf öğrencilerinin tercih edilmesinde etkili olmuştur.

\section{Ölçme Aracının Geliştirilmesi}

Çok maddeli ölçek türlerinden olan likert ölçekleri, uygulandığı kaynak kişilerin her duruma cevap verebildiği ölçeklerdir. Böylece kaynak kişilerin maddelerden ne kadarına katıldığı ve katılma derecesi belirlenebilir. (Balcı, 2001).

Ölçeğin geliştirilmesi sürecinde ilkin alanyazın taraması yapılmış, benzer olarak (MEB, 2006; Çakıcı, 2005; Göçer, 2014; Gömleksiz, 2004; İşeri ve Ünal, 2010; Karasakaloğlu ve Saracaloğlu, 2009; Özbay, Bağcı, Uyar, 2008; Özbay ve Uyar, 2009; Sallabaş, 2008; Sevim, 2012; Ünal, 2006; Yalınkılıç, 2007; Yücel, 2005; Topçuoğlu Ünal ve Köse, 2014) tarafından geliştirilmişve uyarlanmış tutum ölçekleri incelenmiştir. Ardından ölçeğin uygulanacağı 7. sınıf öğrencilerine öğrenci çalışma kitaplarında yer alan etkinlik örnekleri gösterilmiş ve bu örneklerden hareketle Türkçe etkinliklerine yönelik duygu ve düşüncelerinin yer aldığı metinler yazdırı mıştır. Öğrencilerin yazılı anlatımları çözümlenerek, tu tum cümleleri oluşturulmuştur. Olumlu ve olumsuz yargılar taşıyan bu cümleler "tamamen katılıyorum", "katılıyorum", "kararsızım", "katılmıyorum", "hiç katılmıyorum” ifadeleriyle beşli likert şeklinde derecelendirilmiştir. Bu şekilde ortaokul 7. sınıf öğrencilerinin Türkçe etkinliklerine yönelik tutumlannı ifade edebilecek 42 olumlu ve olumsuz tutum cümlesi oluşturulmuştur. Beş uzmanın görüşleri doğrultusunda olgusal nitelik taşıdığı gerekçesiyle 13 madde ölçekten çıkarılmıştır. Ölçek 124 kişilik7. sınıflardan oluşan öğrenci grubuna uygulanmıştır. 29 maddelik tutum cümlesinin 15-18 dakika aralığında yanıtlandığı görülmüştür. Böylelikle zaman faktörünün iç güvenirliği olumsuz yönde etkilemeyeceği ön görülmüştür. Taslak ölçek formu, dil ve anlatım yönünden incelenmiş, gerekli 
Türkçe Dersi Etkinliklerine Yönelik Tutum Ölçeği Geliştirilmesi: Geçerlilik ve Güvenirlik Çalışması

düzeltmeler yapılmış, taslak ölçek formuna son şekli verilerek geçerlik ve güvenirlik uygulamalarının yapılabileceği duruma getirilmiştir.

Gerekli düzenleme ve düzeltmelerden sonra 29 maddelik deneme ölçeği ortaokul 7. sınıflarda öğrenim gören (257 erkek, 269 kız) 526 öğrenciye uygulanmıştır.

Türkçe dersi etkinlikleri tutum ölçeğinin geliştirilmesine yönelik uygulamalar sonucunda derlenen veriler bilgisayara aktarılmışır. Ölçeği cevaplayan her bir öğrenci 'tamamen katılıyorum, katılıyorum, kararsızım, katılmıyorum, hiç katıl mıyorum' şeklinde her bir madde için beşli dereceleme boyutunda tepkide bulunmuştur. Olumlu maddeler 5-4-3-2-1 olarak puanlanırken olumsuz maddeler ise 1-2-3-4-5 şeklinde puanlanmıştır. Türkçe etkinliklerini uygulamaya yönelik tutumun yüksek ya da düşük olması ölçeklerden elde edilen puanların yüksekya da düşük olmasıyla doğru orantılıdır. Deneme uygulaması tamamlanan tutum cümleleri puanlanmış ardından, ölçütlere uymayan maddeleri belirlemek adına madde analizi yapılmıştır.

\section{Bulgular ve Yorum}

Açımlayıcı faktör analiziyle ölçeğin yapı geçerliği belirlenmiştir. "Faktör analizi yapı geçerliğine ilişkin, ‘bu testten elde edilen puanlar, testin ölçtüğünü varsaydığı şeyi ölçüyor mu?’ sorusuna cevap arar. Yapı geçerliğini incelemede amaç, ölçeğin faktör yapısını ortaya çıkartmak ise açımlayıcı faktör analizi tekniği kul lanılır." (Büyüköztürk, Çakmak, Akgün, Karadeniz ve Demirel, 2014, s. 119). Tavşancıl, açımlayıcı faktör analizini "araştırmacının ölçme aracının ölçtüğü faktörlerin sayısı hakkında bir bilgisinin olmadığı, belli bir hipotezi sınamak yerine, ölçme aracıyla ölçülen faktörlerin doğası hakkında bir bilgi edinmeye çalıştığı inceleme türleri" olaraktanımlar (2002, s. 46). Bu çalışmada faktör analizine ilişkin temel kavramlardan biri olan faktör yüklerinin alt eşiği .40 olarak belirlenmiştir. Büyüköztürk (2011) faktör yüklerinin alt eşiğinin .30'un üzerinde olmasını madde sayısının az olduğu bu tür çalışmalar için iyi bir ölçü olarak değerlendirmektedir.

Ölçme aracının faktör analizine uygunluğu KMO (Kaiser-Meyer-Olkin) değeri ve Bartlett's Testi değeri ile hesaplanmıştır.

Tablo 1: Türkçe Etkinliklerine Yönelik Tutum Ölçeğine ilişkin ve Bartlett's testi değeri

\begin{tabular}{lc}
\hline Kaiser-Meyer-Olkin Değeri & 0,962 \\
\hline Bartlett's Testi Değeri & 6987,170 \\
\hline
\end{tabular}

KMO (Kaiser-Meyer-Olkin) ve Barlett Testi derlenen verilerin faktör analizi için uygunluk derecesini belirlemek adına yapılmıştır. Analiz sonucunda KMO değeri .962 ve Barlett testi sonucu ise .00 anlamlı olarak bulunmuştur. ( $p<.05)$ Çalışmada KMO değerinin 0.90 ve 1.00 aralığında olması "mükemmel" olarak yorumlanmaktadır (Şencan, 2005.) Barlett Testi sonucunda elde edilen [ ${ }^{*} \chi 2=6987.170 ; \mathrm{df}=496$, 
$p<.00]$ değeri anlamlı bulunmuştur. Her iki sonuca göre verilerin açımlayııı faktör analizi için uygun olduğunu söylemek mümkündür.

Tablo 2: Türkçe Etkinlikleri Tutum Ölçeği Scree plot grafiğini gösteren tablo

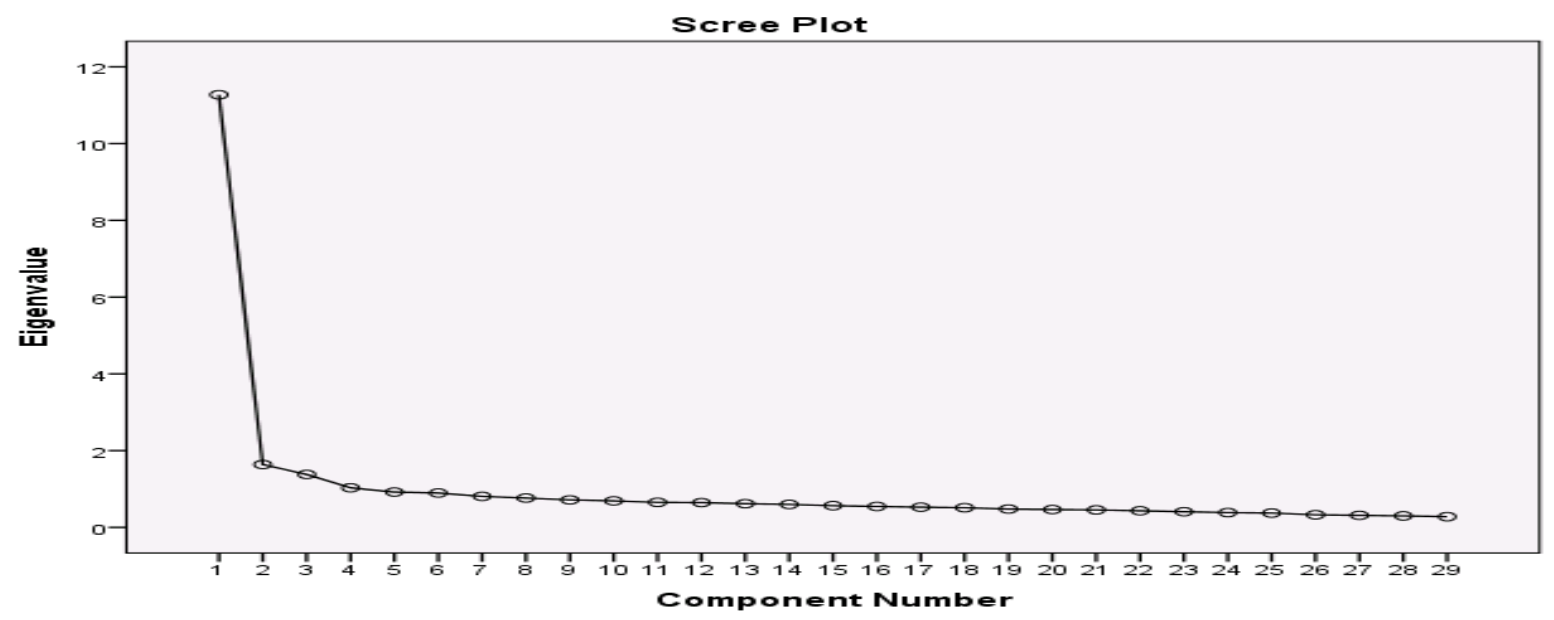

Temel bileşenler çözümlemesi ve varimax tekniği ile yapılan döndürme uygulam asıyla özdeğeri 1.00 ' den büyük olan 3 faktör bulunmuştur. Bu faktörlerin yamaç eğim testi yapılmış, faktör sayısının üç olmasına karar verilmiştir.

Temel bileşenler analizi ve varimax döndürme tekniği ile ölçekte kalacak maddelerin belirlenmesi amaçlanmıştır. Tabachnick ve Fidell (2007) temel bir kural olarak her bir maddenin yük değerinin .32 ve daha üzerinde olması gerektiğini belirtmektedir. Büyüköztürk, "Yüksek iki yük değeri arasındaki farkın ise en az .10 olmasını önermektedir. Aksi durumda birden çok faktörde yüksek yük değeri veren madde binişik madde olarak tanımlanmaktadır." (2011, s. 125). Maddelerin güvenirlikleri için düzeltilmiş madde korelasyon eşik değeri olarak .20 değeri alınmıştır. Bu eşik değerler dikkate alınarak analiz tekrarlanmış ve maddeler seçilmiştir.

Belirtilen ölçütlere uygun yapılan faktör analizi sonucunda 2, 8, 10, 12, 27 ve 29 numaralı toplam 6 madde binişiklik oluşturduğu; 24. madde ise düzeltilmiş madde toplam korelasyonu eşik değerin (.20) altında kaldığı gerekçesiyle ölçekte yer almamıştır. Ölçekte kalan toplam 22 madde 3 faktör oluşturmaktadır. Maddelerin aldıkları yük değerleri ile madde toplam korelasyonu analiz sonuçları Tablo 3'te yer almaktadır. 
Tablo 3: Türkçe Etkinlikleri Tutum Ölçeği açımlayıcı faktör analizi sonuçları

\begin{tabular}{|c|c|c|}
\hline & $\begin{array}{l}\text { Döndürülmüş } \\
\text { Faktör Yük } \\
\text { Değeri }\end{array}$ & $\begin{array}{c}\text { Düzel tilmiş } \\
\text { Madde Toplam } \\
\text { Korelasyonu }\end{array}$ \\
\hline \multicolumn{3}{|l|}{ 1. Faktör: yarar, önem } \\
\hline m22- Türkçe etkinlikleri başarımı artırır. & .719 & .676 \\
\hline m20- Türkçe etkinlikleriyle yeni şeyler öğrenirim. & .716 & .687 \\
\hline m15- Türkçe etkinlikleri önemlidir. & .708 & .683 \\
\hline m21- Türkçe etkinlikleriyle kendimi değerlendiririm. & .675 & .676 \\
\hline m19- Türkçe etkinlikleri yaparak öğrendiklerimi pekiştiririm. & .656 & .633 \\
\hline $\begin{array}{l}\text { m18- Türkçe etkinlikleriyle öğrendiklerimi günlük hayatta } \\
\text { kullanırım. }\end{array}$ & .649 & .624 \\
\hline m26- Türkçe etkinlikleriyle yanlış bildiklerimi düzel tirim. & .590 & .570 \\
\hline $\begin{array}{l}\text { m25.Türkçe etkinliklerini yaparken görevlerimi uygun şekilde } \\
\text { yerine getiririm. }\end{array}$ & .522 & .486 \\
\hline m5 Türkçe etkinlikleri beni geliştirir. & .538 & .617 \\
\hline $\begin{array}{l}\text { m9- Türkçe etkinlikleri diğer derslerdeki başarımı da etkiler. } \\
\text { 2. Faktör: ilgi }\end{array}$ & .475 & .498 \\
\hline m14. Türkçe etkinliklerinin sayısının daha çok olması gerekir. & .640 & .558 \\
\hline m7- Boş zamanlarımda Türkçe etkinlikleri yapmayı tercih ederim. & .656 & .562 \\
\hline $\begin{array}{l}\text { m17. Türkçe etkinliklerini diğer etkinliklere göre daha çok } \\
\text { severek yaparım. }\end{array}$ & .642 & .680 \\
\hline m11.Türkçe etkinlikleriyle uğraşırken kendimi rahat hissederim. & .601 & .559 \\
\hline m1- Türkçe etkinliklerini yapmak beni mutlu eder. & .605 & .715 \\
\hline m3- Türkçe etkinlikleri ilgi çekicidir. & 609 & .565 \\
\hline $\begin{array}{l}\text { m28. Türkçe etkinlikleri diğer etkinliklerden daha önemlidir. } \\
\text { 3. Faktör: isteksizlik ilgisizlik }\end{array}$ & .437 & .446 \\
\hline m6- Mecbur olmasam Türkçe etkinliklerini yapmam. & .667 & .623 \\
\hline m4- Türkçe etkinlikleri kafamı karıştırır. & .635 & .417 \\
\hline m13. Türkçe etkinliklerini anlaşılmaz bulurum. & .591 & .557 \\
\hline m16- Türkçe etkinlikleri çok zamanımı alır. & .425 & .567 \\
\hline $\begin{array}{l}\text { m23. Türkçe etkinliklerine ders dışında zaman ayırmak } \\
\text { gereksizdir. }\end{array}$ & .476 & .555 \\
\hline
\end{tabular}

Tablo 4: Türkçe Dersi Etkinlikleri Tutum Ölçeği açımlayıcı faktör analizi sonuçları

\begin{tabular}{lccc}
\hline \multicolumn{1}{c}{ Faktörler } & $\begin{array}{c}\text { Özdeğer } \\
\text { (Eigenvalues) }\end{array}$ & $\begin{array}{c}\text { Varyans Yüzdesi } \\
(\%)\end{array}$ & Toplam Varyans (\%) \\
\hline Faktör 1: yarar, önem & 11.272 & 20.735 & 20.735 \\
Faktör 2: ilgi & 1.639 & 15.034 & 35.769 \\
Faktör3: isteksizlik, ilgisizlik & 1.379 & 13.507 & 49.276 \\
\hline
\end{tabular}

Tablo 4'te ölçeğin tümünün toplam varyansın \%49.276'sını karşılaması ölçekteki yapının iyi ölçülme oranının yüksek olduğunu göstermektedir. İlgili yapının iyi ölçülme oranı ile açıklanan varyans yüzdesi arasında doğru orantılı bir ilişki söz konusudur. Açıklanan varyans yüzdesi arttıkça ilgili yapının da aynı oranda iyi ölçüldüğü kabul edilir (Büyüköztürk, 2011).

Tablo 3 incelendiğinde 22 madde için faktör yük değerlerinin .425 ile .719 arasında değiştiği, ölçekte yer alan maddelerden 10’unun birinci faktörde (m22, m20, m15, m21, m19, m18, m26, m25, 
m5, m9) 7'sinin ikinci faktörde ( m14, m7, m17, m11, m1, m3, m28) ve 5'inin de üçüncü faktörde( m6, m4, m13, m16, m23) yer aldığı görülmektedir.

Ölçeğin "yarar ve önem" faktöründe bulunan 10 maddenin bulunmaktadır. Döndürülmüş faktör yük değerlerinin .475 - .719 aralığında ol duğu görülmektedir. Bu faktöre ilişkin açıklanan varyans yüzdesi \%20.735 olarak bulunmuştur.

Ölçeğin “ilgi” faktöründeyer alan 7 maddenin yöntemiyle döndürülmüş faktör yük değerlerinin .437 - .640 aralığında olduğu görülmektedir. Bu faktöre ilişkin açıklanan varyans ise \%15.034 olarak bulunmuştur.

Ölçeğin "isteksizlik, ilgisizlik" faktöründe yer alan 5 maddenin döndürülmüş faktör yük değerlerinin .425 - .667 aralığında olduğu görülmektedir. Bu faktöre ilişkin açıklanan varyans ise \%13.507 olarak bulunmuştur.

Ölçeğin yapı geçerliliğini ortaya koymak amacıyla pearson korelasyon katsayıları hesaplanmıştır.

Tablo 5: Ölçek puanları ile ölçüt arasındaki korelasyon analiz sonuçları

\begin{tabular}{lccc}
\hline & Faktör1 & Faktör2 & Faktör3 \\
\hline Faktör1 & 1 & $.696^{* *}$ & $.693^{* *}$ \\
Faktör2 & $.696^{* *}$ & 1 & $.700^{* *}$ \\
Faktör3 & $.693^{* *}$ & $.700^{* *}$ & 1 \\
\hline
\end{tabular}

$* * \mathrm{p}<0.01$

Tablo 5’e göre Türkçe Etkinlikleri Tutum Ölçeğinin faktörleri arasındaki ilişki anlamlı orta ve yüksek düzeydedir. Korelasyon katsayısının mutlak değerinin .70-1.00 ve .69-.30 aralıklarında olması ilişki bakımından orta ve yüksek düzeyde bir ilişki olduğu şeklinde yorumlanmaktadır (Büyüköztürk, 2011). Bu durum, faktörlerden birine karşı artan olumlu ya da olumsuz tutumun diğer faktörleri de aynı şekilde etkilediğine işaret etmektedir.

Türkçe Dersi Etkinlikleri Tutum Ölçeğinin güvenirlik değerlerini belirlemek için Cronbach Alfa İç Tutarlılık katsayısı hesaplanmıştır. İç tutarlılık katsayısı 947 olarak bulunmuştur. Ölçeğin belirlenen faktörler bakımından güvenirliğine Tablo 6’da yer verilmiştir.

Tablo 6: Faktörlerin güvenirlik katsayıları

\begin{tabular}{lc}
\multicolumn{1}{c}{ Etkinlik tutum ölçeği } & Cronbach Alfa Iç Tutarlılık Katsayısı \\
\hline Faktör 1: yarar, önem & $\alpha=.904$ \\
Faktör 2: ilgi & $\alpha=.852$ \\
Faktör 3: isteksizlik, ilgisizlik & $\alpha=.845$ \\
Ölçeğin iç tutarlılık katsayısı & $\alpha=.947$ \\
\hline
\end{tabular}


Türkçe Dersi Etkinliklerine Yönelik Tutum Ölçeği Geliştirilmesi: Geçerlilik ve Güvenirlik Çalışması

Türkçe Etkinlikleri Tutum Ölçeğinin iç tutarlılık katsayıları; birinci faktör olan yarar, önem ” boyutu için .904 ikinci faktör olan “ilgi” boyutu için .852 ve üçüncü faktör olan "isteksizlik, ilgisizlik" boyutu için .845 'tir. Bu değerler, ölçeğin maddelerinin kendi içindeki tutarlılık ve ifade ettiği tutumu yansıtma derecesinin ideal düzeyde olduğunu göstermektedir (Ergin, 1995).

Tablo 7: Faktörlerin ve ölçeğin alt-üst grup bağımsız örneklem t-testi sonuçları

\begin{tabular}{lccccccc}
\hline \multicolumn{2}{c}{ Gruplar } & $\mathrm{N}$ & Mean & Std. Deviation & $\begin{array}{c}\text { Std. Error } \\
\text { Mean }\end{array}$ & $\mathrm{t}$ & $\mathrm{p}$ \\
\hline Faktör1 & Alt grup & 142 & 2.8676 & .70826 & .05944 & -28.333 & $.000^{*}$ \\
& Üst grup & 142 & 4.6690 & .26901 & .02257 & -28.333 \\
Faktör2 & Alt grup & 142 & 2.0379 & .59250 & .04972 & -32.229 & $.000^{*}$ \\
& Üst grup & 142 & 4.0290 & .43700 & .03667 & -32.229 & \\
Faktör3 & Alt grup & 142 & 2.7034 & .64255 & .05392 & -30.936 & $.000^{*}$ \\
& Üst grup & 142 & 4.5955 & 34389 & .02886 & -30.936 \\
\hline
\end{tabular}

$* \overline{\mathrm{p}}<0.05$

Tablo 7 incelendiğinde alt grupla üst grubun tutum puanları aritmetik ortalamaları arasında anlamlı farklılık görülmektedir ( $p=.00<.05)$.

Ölçek maddelerinin "t değeri” bakımından üst grup lehine anlamlı olduğu görülmektedir. Elde edilen bu bulgular Türkçe etkinliklerine yönelik tutum ölçeğinin faktörlerin ve ölçeğin alt grup ve üst grubu ayırt edebildiğini yani iç geçerliğe sahip olduğunu göstermektedir.

\section{Sonuç}

Öğrencilerin Türkçe dersi etkinliklerine yönelik tutumları, etkinlikleriamaca uygun yapmalarını önemli ölçüde etkilemektedir. Bu etkinlikler yoluyla dil becerilerinin geliştirilmesi sürecinde zihinsel, duygusal ve sosyal becerilerin geliştirilmesi de amaçlanmıştır. Bu durum Türkçe dersi etkinliklerinin önemini artırmaktadır. Bu çalışmada ortaokul öğrencilerinin Türkçe dersindeki etkinliklere yönelik tutumlarını belirlemek amacıyla bir ölçek geliştirilmiş ve ölçeğin geçerlik ve güvenirlik çalışmaları yapılmıştır. Ölçek geliştirme sürecinde madde havuzu oluşturulmasında ilkin 7. sınıf öğrencilerine, Türkçe etkinlikleriyle ilgili duygu ve düşüncelerine yer verdikleri bir metin yazdııı mıştır. İçerik analizi ile oluşturulan maddeler taslak ölçekte yer almıştır. Uzman görüşü ve pilot de neme aşamasının ardından gerekli düzeltmeler yapılan ölçek 526 ortaokul 7. Sınıf öğrencisine uygulanmıştır. Ölçeğin analizleri SPSS 20.0 programı kullanılarak yapıl mıştır. Çalışmada KMO değeri .962 olarak belirlenmiştir. Bu değerin .90 üzerinde olması "mükemmel" olarak yorumlanmaktadır. Barlett Testi değeri [ $\left.{ }^{*} \chi 2=6987.170 ; d f=496, p<.00\right]$ anlamlı olarak bulunmuştur. Bu sonuçlar veri setinin açımlayıc faktör analizi için uygun olduğunu göstermektedir. Uygulanan ölçekte yer alan 29 madde analiz edilmiştir. 
Açımlayııı faktör analizi sonuçlarına göre 22 maddeye sahip 3 faktörü olan 5'li likert tipinde bir ölçek elde edilmiştir. Maddelerden 17'si olumlu, 5'i olumsuz tutum ifadesine sahiptir.

Faktörlerin ve ölçeğinalt-üst grup bağımsız örneklem t-testi sonuçları, faktörlerinve ölçeğin alt ve üst grupları ayırt edicilik özelliğine sahip olduğunu göstermektedir.

Bütün bu ölçek geliştirme süreci sonunda ulaşılan geçerlik ve güvenirlik değerleri ölçeğin Türkçe dersi etkinliklerine yönelik tutumu ölçebilecek özelliklere sahip olduğunu göstermektedir. Geliştirilen ölçeğin öğrencilerin Türkçe dersi etkinliklerine yönelik tutumlarını belirlemede etkili olacağı düşünülmektedir.

\section{Kaynaklar}

Balcı, A. (2001). Sosyal bilimlerde araştırma: yöntem, teknik ve ilkeler. Ankara: Pegem A Yayıncılık.

Büyüköztürk, Ş. (2011). Sosyal bilimler için veri analizi el kitabı. (14. baskı). Ankara: Pegem Akademi.

Büyüköztürk, Ş., Çakmak, E. K., Akgün, Ö. E., Karadeniz, Ş. ve Demirel, F. (2014). Bilimsel araştırma yöntemleri. (18. Baskı). Ankara: Pegem Akademi Yayınları.

Çakıcı, D. (2005). Ön örgütleyicilerin okumaya yönelik tutum ve okuduğunu anlama üzerindeki etkileri. Yayımlanmamış Doktora Tezi, Dokuz Eylül Üniversitesi, İzmir.

Ergin, Y. D. (1995). Ölçeklerdegeçerlik ve güvenirlik. M.Ü. Atatürk Eğitim Fakültesi Eğitim Bilimleri Dergisi, 7, 125-148. Internetten 12.03.2016'da http://dspace.marmara.edu.tr/handle/11424/3689 adresinden alınmıştır.

Göçer, A. (2014). Yazma Tutum Ölçeği'nin (ytö) Türkçeye uyarlanması: geçerlik ve güvenirlik çalışması. Kastamonu Eğitim Dergisi, 22 (2), 515-524.

Gömleksiz, M.N. (2004). Kitap okuma alışkanlığına ilişkin bir tutum ölçeğinin geçerlik ve güvenirliği. Fırat Üniversitesi Sosyal Bilimler Dergisi, 2 (14), 185-195.

Güneş, F. (2009). Türkçe öğretiminde günümüz gelişmeleri ve yapılandırıcı yaklaşım. Mustafa Kemal Üniversitesi Sosyal Bilimler Enstitüsü Dergisi, 6 (11), 1-21.

Güneş, F. (2012). Testlerden etkinliklere Türkçe öğretimi. Dil ve Edebiyat Eğitimi Dergisi, 1 (1), 31-42.

Güneş, F. (2013). Türkçede metin öğretimi yerine metinle öğrenme. Adıyaman Üniversitesi Sosyal Bilimler Enstitüsü Dergisi, 6 (11).

İşeri, K. ve Ünal, E. (2010). Yazma Eğilimi Ölçeği'nin Türkçeye uyarlanması. Eğitim ve Bilim, 35 (155), 104-117.

Karasakaloğlu, N. ve Saracaloğlu, A., S. (2009). Sınıf öğretmeni adayla rının Türkçe derslerine yönelik tutumları, akademik benlik tasarımlarıile başarıları arasındaki ilişki. Yüzüncü Yıl Üniversitesi Eğitim Fakültesi Dergisi, 5 (1), 343-362.

Karasar, N. (2006). Bilimsel araştırma yöntemleri. Ankara: Nobel Yayın Dağıtım.

Kavcar, C., Oğuzkan, F., \& Sever, S. (2005). Türkçe öğretimi. (7. Baskı). Ankara:Engin Yayınevi

Kurudayığlu, M., ve Çetin, Ö. (2015). Temel beceriler ve Türkçe Öğretimi. Ana Dili Eğitimi Dergisi, 3 (3), 1-19.

Millî Eğitim Bakanlığı. (2006). Ilköğretim Türkçe dersi (6, 7, 8. sınıflar) öğretim programı. Ankara: Devlet Kitapları Müdürlüğü.

Nunan, D. (2001). Designing tasks for the communicative classroom. Cambridge University Press.

Özbay, M. (2009). Okuma eğitimi. Ankara: Öncü Kitap. 
Türkçe Dersi Etkinliklerine Yönelik Tutum Ölçeği Geliştirilmesi: Geçerlilik ve Güvenirlik Çalışması

Özbay, M., Uyar, Y. (2009). İlköğretim ikinci kademe öğrencileri için okumaya yönelik tutum ölçeğinin geliştirilmesi: Geçerlilik ve güvenirlik çalışması. E-Journal of New World Science Academy, 4 (2), 632 651. Internetten 13.03.2016' da http://dergipark.ulakbim.gov.tr/nwsaedu/article/view/5000063610/5000094869 adresinden alınmıştır.

Özbay, M., Bağcı, H. ve Uyar, Y. (2008). Türkçe öğretmeni adaylarının okuma alışkanlığına yönelik tutumlarının çeşitli değişkenlere göre değerlendirilmesi. Inönü Üniversitesi Eğitim Fakültesi Dergisi, 9 (15), 117136.

Richards, J.\& Rodgerds, T. (1986). Approaches and methods in language teaching. Cambridge: Cambridge University Press.

Sallabaş, M.E. (2008). ílköğretim 8. sınıf öğrencilerinin okumaya yönelik tutumları ve okuduğunu anlama becerileri arasındaki ilişki. Inönü Üniversitesi Eğitim Fakültesi Dergisi, 9 (16), 141-155.

Sevim, O. (2012). Öğretmen a daylarına yönelik konuşma kaygısı ölçeği : bir geçerlik ve güvenirlik çalışması. Turkish Studies, 7 (2), 927-937.

Şencan, H. (2005). Sosyal ve davranışsal ölçümlerde güvenilirlik ve geçerlilik. Ankara: Seçkin Yayıncılık.

Tabachnick, G.B. ve Fidell, L.S. (2007). Using multivariate statistics. (5.Edition). Needham Height, MA: Allyn \& Bacon.

Tavşancıl, E. (2002). Tutumların ölçülmesi ve spss ile veri analizi. Ankara: Nobel Yayınevi.

Topçuoğlu, Ünal, F., ve Köse, M. (2014). Türkçe dersine yönelik tutum ölçeği geliştirilmesi: bir geçerlilik ve güvenirlik çalışması. Bartın Üniversitesi Eğitim Fakültesi Dergisi, 3 (2), 233-249.

Ünal, E. (2006). Ilköğretim öğrencilerinin eleştirel okuma becerileri ile okuduğunu anlama ve okumaya ilişkin tutumları arasındaki ilişki. Yayınlanmamış Yüksek Lisans Tezi. Osmangazi Üniversitesi, Eskişehir.

Yalınkılıç, K. (2007). Türkçe öğretmen a daylarının okumaya ilişkin tutum ve görüşleri. Uluslararası Sosyal Araştırmalar Dergisi. 1 (1), 225-241.

Yücel, G. (2005). Okulöncesinde Okuma Tutumları Ölçeği’nin geçerlik ve güvenirlik çalışması. Yayımlanmamış Yüksek Lisans Tezi. Gazi Üniversitesi, Ankara. 


\section{EK-1. Türkçe Etkinlikleri Tutum Ölçeği}

\section{Sevgili öğrenci;}

Her bir cüml eyi okuyarak sizin duygu ve düşüncelerinize en uygun seçeneği işaretleyiniz.

Bu bir sınav değildir. Cüml elerin hiçbirinin kesin olarak doğru cevabı yoktur. Kesinlikle isim, numara ve okul yazmayınız. Lütfen, her bir seçeneği okuduktan sonra aklınıza ilk gelen seçeneği (X) işareti koyarak işaretleyiniz. Her cümleyi baştan sona okuduktan sonra; Hiç Katılmıyorum, Katılmıyorum, Kararsızım, Katılıyorum ve Tamamen Katılıyorum Seçeneklerinden yalnızca birini işaretleyiniz. Şimdi her cümleyi sıra ile okuyup, duygularınıza göre en uygun olan seçeneği işaretleyin.

\begin{tabular}{|c|c|c|c|c|c|}
\hline $\begin{array}{l}\text { Cinsiyet: Erkek ( ) Kız ( ) } \\
\text { Sınıf: 6( ) 7( ) }\end{array}$ & 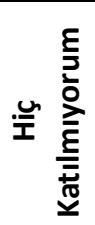 & 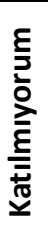 & 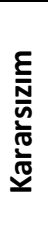 & 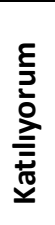 & 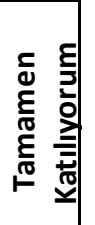 \\
\hline 1. Türkçe etkinliklerini yapmak beni mutlu eder. & & & & & \\
\hline 2. Türkçe etkinlikleri ilgi çekicidir. & & & & & \\
\hline 3. Türkçe etkinlikleri kafamı karıştırır. & & & & & \\
\hline 4. Türkçe etkinlikleri beni geliştirir. & & & & & \\
\hline 5. Mecbur olmasam Türkçe etkinliklerini yapmam. & & & & & \\
\hline 6. Boş zamanlarımda Türkçe etkinlikleri yapmayı tercih ederi & & & & & \\
\hline 7. Türkçe etkinlikleri diğer derslerdeki başarımı da etkiler. & & & & & \\
\hline 8.Türkçe etkinlikleriyle uğraşırken kendimi rahat hissederim & & & & & \\
\hline 9. Türkçe etkinliklerini anlaşıl maz bulurum. & & & & & \\
\hline 10. Türkçe etkinliklerinin sayısının daha çok olması gerekir. & & & & & \\
\hline 11. Türkçe etkinlikleri önemlidir. & & & & & \\
\hline 12. Türkçe etkinlikleri çok zamanımı alır. & & & & & \\
\hline $\begin{array}{l}\text { 13. Türkçe etkinliklerini diğer etkinliklere göre daha çok sever } \\
\text { yaparım. }\end{array}$ & & & & & \\
\hline $\begin{array}{l}\text { 14. Türkçe etkinlikleriyle öğrendiklerimi günlük haya } \\
\text { kullanırım. }\end{array}$ & & & & & \\
\hline 15. Türkçe etkinlikleri yaparak öğrendiklerimi pekiştiririm. & & & & & \\
\hline
\end{tabular}


Türkçe Dersi Etkinliklerine Yönelik Tutum Ölçeği Geliştirilmesi: Geçerlilik ve Güvenirlik Çalışması

(Devamı) EK-1. Türkçe Etkinlikleri Tutum Ölçeği

\begin{tabular}{|c|c|c|c|c|c|}
\hline & 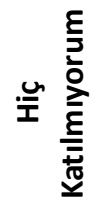 & 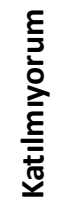 & 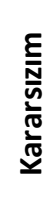 & 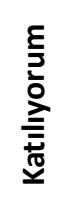 & 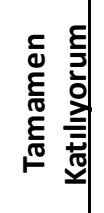 \\
\hline 16. Türkçe etkinlikleriyle yeni şeyler öğrenirim. & & & & & \\
\hline 17. Türkçe etkinlikleriyle kendimi değerlendiririm. & & & & & \\
\hline 18. Türkçe etkinlikleri başarımı artırır. & & & & & \\
\hline $\begin{array}{l}\text { 19. Türkçe etkinliklerine ders dışında zaman ayırn } \\
\text { gereksizdir. }\end{array}$ & & & & & \\
\hline $\begin{array}{l}\text { 20.Türkçe etkinliklerini yaparken görevlerimi uygun şeki } \\
\text { yerine getiririm. }\end{array}$ & & & & & \\
\hline 21. Türkçe etkinlikleriyle yanlış bildiklerimi düzel tirim. & & & & & \\
\hline 22. Türkçe etkinlikleri diğer etkinliklerden daha önemlidir. & & & & & \\
\hline
\end{tabular}

